N.M. Palibroda, O.I. Fediv

\title{
SOME ASPECTS OF PATHOGENESIS OF EROSIVE-ULCEROUS GASTRIC LESIONS IN LIVER CIRRHOSIS PATIENTS
}

Bukovinian State Medical University, Chernivtsi, Ukraine

\begin{abstract}
Von Willebrand factor, tumor necrosis factor- $\alpha$ levels and portal bloodstream were examined in 47 patients with liver cirrhosis and 8 apparently healthy persons. The increase of von Willebrand factor and tumor necrosis factor- $\alpha$ levels were found to lead to the development of erosive-ulcerative lesions of gastric mucosa. The abnormalities of portal resistance, von Willebrand factor
\end{abstract}

Introduction. Congestive phenomena in the vascular system in case of portal hypertension, especially pronounced in the microcirculation, hypoxia, stasis, erythrocyte aggregation, and endotoxemia result in disorders of the erythrocyte morphofunctional properties in liver cirrhosis patients and vasculopathy [8]. The vascular intima of these patients is considerably injured, epithelial desquamation, bare and swollen basal membrane, neutrophil and fibroblast infiltration, parietal clot formation are found [2, 7]. Endothelial cells lesion leads to von Willebrandfactor (vWF) release - a multimeric glycoprotein participating in platelet adhesion and aggregation, promoting formation of microclots and further disturbance of microcirculation [6].

Intensified release of vWF in vitro is observed under the action of various stimuli including mechanical injury, endotoxins, histamine, complement complex as well as cytokines [4].

Tumor necrosis factor- $\alpha$ (TNF- $\alpha)$ is a multifunctional cytokine with a pronounced pleiotropy, produced by macrophages, lymphocytes, and playing a key role in the development of local and general systemic pathological processes.TNF- $\alpha$ regulates the intensity of inflammation, immune response, possessing hepatotoxic, pyrogenic effects etc. Increased TNF- $\alpha$ production promotes inhibition of the vascular smooth muscles reaction to restricting stimuli, causing hypoxia and sludge-phenomenon, intensifying local and systemic microcirculatory disorders, activating inflammatory process. Besides, TNF- $\alpha$ level increase results in disturbance of mitochondrial respiration and apoptosis stimulation [5].

The purpose of the work is to detect a pathogenetic role of von Willebrand factor, TNF- $\alpha$, portal vein resistance in the development of lesions of the gastric mucus (GM) in patients with liver cirrhosis (LC).

Materials and methods. $47 \mathrm{LC}$ patients were examined. They were divided into three groups depending on the character of GM lesions: the $1^{\text {st }}$ group - LC patients without portal hypertensive gastropathy (PHG) and erosive-ulcerous gastric lesions (EUGL) ( 8 individuals), the $2^{\text {nd }}$ group - LC patients with PHG without EUGL (20 individuals), the $3^{\text {rd }}$ group - LC patients with EUGL against the ground (C) N.M. Palibroda, O.I. Fediv, 2014 and TNF- $\alpha$ are interrelated data which play a certain role in occurrence of erosive-ulcerative lesions of gastric mucosa in patients with liver cirrhosis.

Key words: liver cirrhosis, erosive-ulcerous gastric lesions, von Willebrand factor (vWF), TNF- $\alpha$, congestive index.

of PHG (19 individuals). A comparative group contained 8 practically healthy individuals of corresponding age and sex.

TNF- $\alpha$ and vWF content in the blood plasma was detected by means of ELISA using the set of reagents "Shild Diagnostics" (Great Britain) and "Diaclone" (France) respectively. Doppler examination of the blood flow in the portal vein was carried out in the morning on empty stomach. The portal vein was visualized in the way that the angle between the vessel and detector was less than $60^{\circ}$. The rate of blood flow and the diameter of the portal vein were measured during expiration for 2-3 seconds. The analysis of Doppler curve evaluated congestive index (CI), characterizing the resistance to portal blood flow by means of F.Moriyasu et al method [3]. For visual monitoring changes of gastric mucosa, all patients performed upper endoscopy using endoscope "Olimpus" (Japan). Mathematical analysis of the data was performed on a computer with a processor AMD Athlon 64 via licensing program Primer of Biostatistics. Version 4.03 (S.Glantz, USA) to calculate the average value, the average error and students criteria. Critical significance level when testing statistical hypotheses in this study considered equal to 0,05 .

Results and discussion. The analysis of the results of the research showed that vWF increase in the blood plasma was observed in all the LC patients: in the $1^{\text {st }}$ group of patients up to $10,94 \pm 1,55 \mathrm{IU} / \mathrm{ml}$ $(\mathrm{p}<0,05)$, the $2^{\text {nd }}$ group - up to $16,99 \pm 2,07 \mathrm{IU} / \mathrm{ml}$ $(\mathrm{p}<0,01)$, the $3^{\text {rd }}$ group - up to $18,37 \pm 2,31 \mathrm{IU} / \mathrm{ml}$ $(\mathrm{p}<0,01)$, as compared with PHI $(4,76 \pm 1,70 \mathrm{IU} / \mathrm{ml})$. A clear tendency to the increase of the given index with progressing lesions of GM with a reliable difference between the indices in the $3^{\text {rd }}$ group of patients in comparison with the $1^{\text {st }}$ one $(\mathrm{p}<0,05)$ was found.

The analysis of portal vein resistance showed that $\mathrm{CI}$ increased in all patients with liver cirrhosis: in the $1^{\text {st }}$ group of patients up to $0,055 \pm 0,005(\mathrm{p}>0,05)$, the $2^{\text {nd }}$ group - up to $0,11 \pm 0,01 \quad(\mathrm{p}<0,01)$, the $3^{\text {rd }}$ group - up to $0,22 \pm 0,02(\mathrm{p}<0,01)$. Normal data of $\mathrm{CI}$ was $0,03 \pm 0,003$ in group of healthy people.

The detected direct correlation between vWF and CI $(r=0,71, p<0,01)$ is indicative of the role of endothelial lesion in the pathogenesis of portal circulation disorders in case of LC. 
vWF stimulating the formation of microclots and the progress of microcirculation disorders is likely to play a certain role in progressing of portal hypertension and occurring EUGL in LC patients.

In addition, we have established that increase of TNF- $\alpha$ level in the blood plasma is found in all the LC patients as compared with PHI $(10,96 \pm 1,69 \mathrm{pg} /$ $\mathrm{ml})$ : in the $1^{\text {st }}$ group - up to $20,48 \pm 4,00 \mathrm{pg} / \mathrm{ml}$ $(\mathrm{p}<0,05)$, in the $2^{\text {nd }}$ group - up to $34,22 \pm 6,16 \mathrm{pg} / \mathrm{ml}$ $(\mathrm{p}<0,001)$, in the $3^{\text {rd }}$ group - up to $59,34 \pm 9,27 \mathrm{pg} / \mathrm{ml}$ $(p<0,001)$, with a reliable difference of indices in the $3^{\text {rd }}$ group as compared with other groups $(p<0,05$ $0,01)$.

Thus, a maximal value of TNF- $\alpha$ level in the blood plasma was in the $3^{\text {rd }}$ group of patients which is indicative of its possible role in the pathogenesis of EUGL in LC patients.

In addition, the conducted correlation-regressive analysis of the $3^{\text {rd }}$ group of patients indicated that TNF- $\alpha$ in LC patients is one of the important factors of portal circulation disorders and endothelial lesions, which is proved by close correlation relations between the content of this cytokine in the blood plasma and Doppler findings of the portal circulation (TNF- $\alpha-C I, r=0,731, p<0,001$ ), the level of vWF in the blood plasma (TNF- $\alpha-v W F, r=0,554, p<0,05$ ).

Experimental studies showed that TNF- $\alpha$ promotes the activation of stellate cells, increased production of the hepatic-cellular matrix (HCM) proteins, inhibits apoptosis of the activated stellate cells [2], stimulates NOS and induces production of the blood plasma NO [1,8]. Probably due to these mechanisms TNF- $\alpha$ in case of a considerable increase of its concentration in the blood plasma of patients with LC and EUGL results in intensified intrahepatic vascular resistance and deterioration of Doppler findings of the portal circulation.

At the same time, increased disorders of portal hemodynamics and catabolic properties of TNF- $\alpha$ cause the occurrence of vasculopathy and endothelial lesions, vWF increased level, formation of microclots, promoting further deterioration of microcirculation and progressing of GM lesions.

\section{Conclusions}

1. The patients with liver cirrhosis and erosiveulcerous gastric lesions detect a reliable increase of von Willebrand factor which is indicative of endothelial lesions and progressing of microcirculatory disorders in such patients.

2. Maximal violation of portal blood flow (increased congestive index) is found in patients with erosive and ulcerative lesions of the stomach and PHG.

3. Tumor necrosis factor- $\alpha$ can be considered as one of the important mediators of portal circulative disorders, endothelial lesions and occurrence of erosive-ulcerous lesions of the gastric mucus in patients with liver cirrhosis.

Prospects for further research in this area are to improve methods of treatment of lesions of the gastric mucosa in patients with liver cirrhosis by correction of detected disturbances.

\section{References}

1. Effects of tumor necrosis factor, endothelin and nitric oxide on hyperdynamic circulation of rats with acute and chronic portal hypertension / J. Wang, G. Gao, R. Gao [et al.] // World J. Gastroenterol. - 2004. - Vol. 10 (5). P. 689-693.

2. Li T. Research progress of vasculopathy in portal hypertension / T. Li, Z. Yang // World J. Gastroenterol. 2005. -Vol. 11 (39). - P. 6079-6084.

3. Measurment of portal vascular resistense in patients with portal hypertension / F. Moriyasy, O. Nishida, N. Ban [et al.] // Gastroenterology. - 1986. - Vol. 90 (3). P. 710-717.

4. Role of cytokines and chemokines in non-alcoholic fatty liver disease / V. Braunersreuther, G. Viviani, F. Mach [et al.] // World J. Gastroenterol. - 2012. - № 18 (8). P. 727-735.

5. Tumor Necrosis Factor-a: Life and Death of Hepatocytes During Liver Ischemia/Reperfusion Injury / M. Shuh, H. Bohorquez, G. Loss [et al.] // The Ochsner J. - 2013. № 13. - P. 119-130.

6. Von Willebrand factor as new noninvasive predictor of portal hypertension, decompensation and mortality in patients with liver cirrhosis / M. Ferlitsch, T. Reiberger, M. Hoke [et al.] // Hepatology. - 2012. - Vol. 56 (4). P. 1439-1447.

7. Von Willebrand factor levels predict clinical outcome in patients with cirrhosis and portal hypertension / V. La Mura, J.C. Reverter, A. Flores-Arroyo [et al.] // Gut. 2011. - Vol. 60 (8). - P. 1133-1138.

8. Yeon Seok Seo. Pathophysiology of Portal Hypertension and Its Clinical Links / Yeon Seok Seo, H. Vijay Shah // Journal of Clinical \& Experimental Hepatology. - 2011. Vol. 1 (2). - P. 87-93.

\section{НЕКОТОРЫЕ АСПЕКТЫ ПАТОГЕНЕЗА ЭРОЗИВНО-ЯЗВЕННЫХ ПОРАЖЕНИЙ ЖЕЛУДКА У БОЛЬНЫХ ЦИРРОЗОМ ПЕЧЕНИ}

\section{Н.М. Палиброда, А.И. Федив}

Резюме. Фактор Виллебранда (ФВ), фактор некроза опухолей- $\alpha$ (TNF- $\alpha)$ и портальный кровоток были исследованы у 47 пациентов с циррозом печени и поражениями желудка (портальная гипертензивная гастропатия, эрозивно-язвенные поражения желудка - ЭЯПЖ). Анализ результатов исследования показал, что уровень ФB, TNF- $\alpha$ в плазме крови и индекс обструкции, который отображает сопротивление портальному кровотоку, возрастал с прогрессированием поражений желудка, достигая максимальных значений у пациентов с ЭЯПЖ. Обнаружена прямая корреляционная связь между ФВ, ТNF- $\alpha$ и индексом обструкции в воротной вене: ФВ-ИО, $\mathrm{r}=0,71(\mathrm{p}=0,01), \mathrm{TNF}-\alpha-$ ИО, $\mathrm{r}=0,731$ ( $\mathrm{p}=0,001)$, TNF- $\alpha-\Phi \mathrm{B}, \mathrm{r}=0,554$ ( $\mathrm{p}=0,04)$. Таким образом, ФВ, способствуя микротромбообразованию и прогрессированию нарушений микроциркуляции, вероятно играет роль в прогрессировании портальной гипертензии и возникновении ЭЯПЖ у больных циррозом печени. TNF- $\alpha$, как известно, способствует активации звездчатых клеток, продуцированию белков печеночного матрикса, приводит к усилению внутрипеченочного сосудистого сопротивления. Вместе с тем, рост нарушений портальной гемодинамики и катаболические свойства TNF- $\alpha$ обус- 
ловливают повреждение эндотелия, повышение уровня ФВ и ухудшение микроцикуляции, что в свою очередь приводит к прогрессированию поражений желудка вплоть до возникновения эрозий и гепатогенных язв.

Ключевые слова: цирроз печени, эрозивно-язвенные поражения желудка, фактор Виллебранда, TNF- $\alpha$, индекс обструкции.

\section{ДЕЯКІ АСПЕКТИ ПАТОГЕНЕЗУ ЕРОЗИВНО-ВИРАЗКОВИХ УРАЖЕНЬ ШЛУНКА У ХВОРИХ НА ЦИРОЗ ПЕЧІНКИ}

\section{Н.М. Паліброда, О.І. Федів}

Резюме. Фактор Віллебранда (ФВ), фактор некрозу пухлин- $\alpha$ (TNF- $\alpha$ ) і портальний кровообіг були досліджені в 47 пацієнтів із цирозом печінки та ураженнями шлунка (портальна гіпертензивна гастропатія, ерозивно-виразкові ураження шлунка - ЕВУШ). Аналіз результатів дослідження показав, що рівень ФВ, TNF- $\alpha$ у плазмі крові та індекс обструкції, який характеризує опір портальному кровотоку, зростали із прогресуванням уражень шлунка, сягаючи максимальних значень у пацієнтів з ЕВУШ. Виявлений прямий кореляційний зв'язок між ФВ, TNF- $\alpha$ та індексом обструкції у ворітній вені: ФВ-IO, r=0,71 (p=0,01), TNF- $\alpha-\mathrm{IO}, \mathrm{r}=0,731$ ( $\mathrm{p}=0,001)$, TNF- $\alpha-\Phi \mathrm{B}, \mathrm{r}=0,554$ ( $\mathrm{p}=0,04)$. Таким чином, ФВ, сприяючи мікротромбоутворенню та порушенню мікроциркуляції, ймовірно відіграє роль у прогресуванні гіпертензії у системі ворітної вени. TNF- $\alpha$, як відомо, сприяє активації зірчастих клітин, продукуванню білків печінкового матриксу, призводить до посилення внутрішньопечінкового судинного опору. Разом з тим патологічні зміни портальної гемодинаміки та катаболічні властивості TNF- $\alpha$ зумовлюють пошкодження ендотелію, підвищення рівня ФВ та погіршення мікроцикуляції. Загалом, зростання показників ФB, TNF- $\alpha$ у плазмі крові та прогресування портальної гіпертензії створюють передумови для розвитку уражень шлунка аж до виникнення ерозій та гепатогенних виразок.

Ключові слова: цироз печінки, ерозивно-виразкові ураження шлунка, фактор Віллебранда, TNF- $\alpha$, індекс обструкції.

Буковинський державний медичний університет (м. Чернівці)

Рецензент - проф. О.І. Волошин

Buk. Med. Herald. - 2014. - Vol. 18, № 2 (70). - P. 86-88

Надійшла до редакції 29.01.2014 року

(C) N.M. Palibroda, O.I. Fediv, 2014 